ҚАЗАҚСТАН РЕСПУБЛИКАСЫ

ҰЛТТЫҚ ҒЫЛЫМ АКАДЕМИЯСЫНЫҢ

Абай атындағы Қазақ ұлттық педагогикалық университетінің
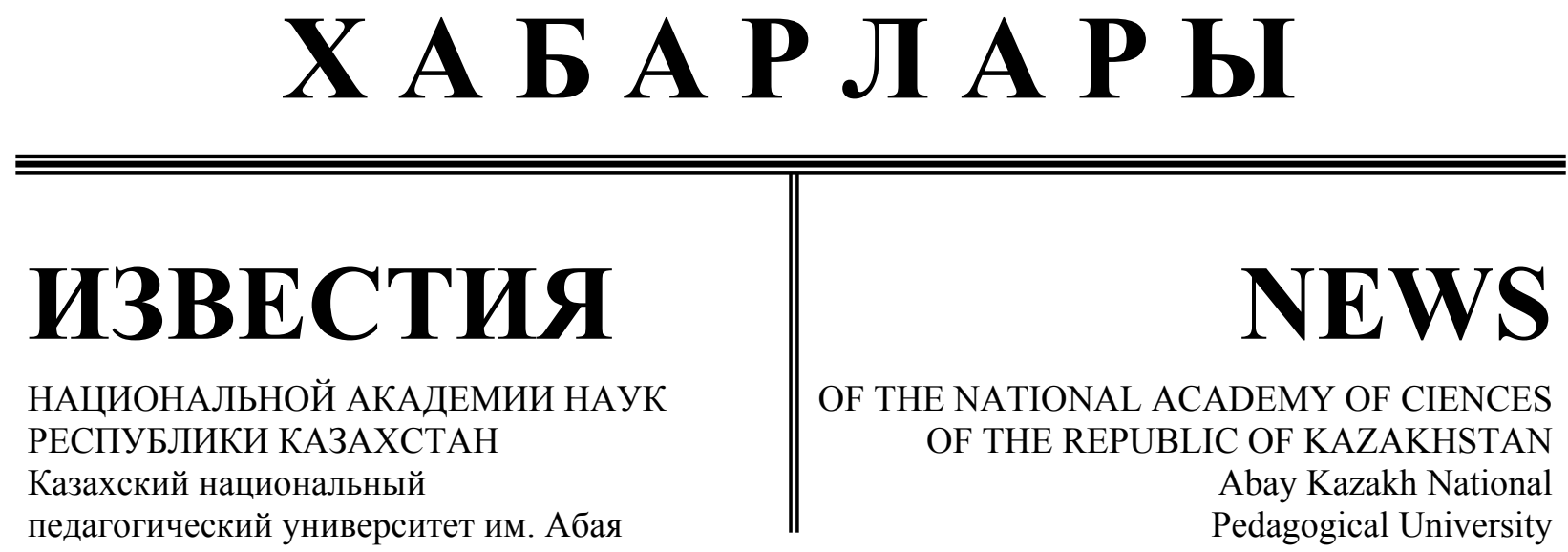

\author{
SERIES \\ OF SOCIAL AND HUMAN SCIENCES
}

2 (330)

MARCH - APRIL 2020

PUBLISHED SINCE JANUARY 1962

PUBLISHED 6 TIMES A YEAR 
Бас редактор

ҚР ҰҒА құрметті мүшесі

Балықбаев Т.O.

Р ед акция а лқ а сы:

экон. ғ. докторы, проф., ҚР ҰҒА академигі Баймұратов У.Б.; филос. ғ.докторы, проф., ҚР ҰҒА академигі Есім Г.Е.; фил. ғ. докторы,, проф., ҚР ҰҒА академигі Қирабаев С.С.; эк. ғ. докторы, проф., ҚР ҰҒА академигі Қошанов А.К.; эк.ғ. докторы, проф., ҚР ҰҒА академигі Нәрібаев К.Н. (бас редактордың орынбасары); филос. ғ.докторы, проф., ҚР ҰҒА академигі Нысанбаев А.Н.; заң ғ. докторы, проф., ҚР ҰҒА академигі Сәбікенов С.Н.; заң ғ. докторы, проф., ҚР ҰҒА академигі Сүлейменов М.К.; эк. ғ. докторы, проф., ҚР ҰҒА академигі Сатыбалдин С.С.; тарих ғ. докторы, проф., ҚР ҰҒА академик Әбжанов Х.М.; тарих ғ. докторы, проф., ҚР ҰҒА корр. мүшесі Әбусеитова М.Х.; тарих ғ. докторы, проф., ҚР ҰҒА академик Байтанаев Б.А.; филол. Ғ. докторы, проф., ҚР ҰҒА корр. мүшесі Жақып Б.А.; фил. ғ. докторы, проф., академик НАН РК Қалижанов У.К.; филол. ғ. докторы, проф., ҚР ҰҒА академик Қамзабекұлы Д.; тарих ғ. докторы, проф., ҚР ҰҒА академик Қожамжарова Д.П.; тарих ғ. док-торы, проф., ҚР ҰҒА академик Қойгелдиев М.К.; фил. ғ. докторы, проф., ҚР ҰҒА корр. мүшесі Құрманбайұлы Ш.; тарих ғ. докторы, проф., ҚР ҰҒА корр. мүшесі Таймағанбетов Ж.К.; социол. ғ. докторы, проф., ҚР ҰҒА корр. мүшесі Шәукенова 3.К.; фил. ғ. докторы, проф., ҚР ҰҒА корр. мүшесі Дербісәлі А.; саяси. ғ. докторы, проф., Бижанов А.К., тарих ғ. докторы, проф., Кабульдинов 3.Е.; фил. ғ. докторы, проф., ҚР ҰҒА корр мүшесі Қажыбек Е.3.

Р еда ц ия ке н е с і:

Молдова Республикасының ҰҒА академигі Белостечник Г. (Молдова); Әзірбайжан ҰҒА академигі Велиханлы Н. (Азербайджан); Тәжікстан ҰҒА академигі Назаров Т.Н. (Тәжікстан); Молдова Республикасының ҰҒА академигі Рошка А. (Молдова); Молдова Республикасының ҰҒА академигі Руснак Г. (Молдова); Әзірбайжан ҰҒА корр. мүшесі Мурадов Ш. (Әзірбайжан); Әзірбайжан ҰҒА корр. мүшесі Сафарова 3. (Әзірбайжан); э. ғ. д., проф. Василенко В.Н. (Украина); заң ғ. докт., проф. Устименко В.А. (Украина)

«Қазақстан Республикасы Ұлттық ғылым академиясының Хабарлары. Қоғамдық және гуманитарлық ғылымдар сериясы».

ISSN 2224-5294

Меншіктенуші: «Қазақстан Республикасының Ұлттық ғылым академиясы» РҚБ (Алматы қ.)

Қазақстан республикасының Мәдениет пен ақпарат министрлігінің Ақпарат және мұрағат комитетінде 30.04.2010 ж. берілген № 10894-Ж мерзімдік басылым тіркеуіне қойылу туралы куәлік

Мерзімділігі: жылына 6 рет.

Тиражы: 500 дана.

Редакцияның мекенжайы: 050010, Алматы қ., Шевченко көш., 28; 219, 220 бөл.; тел.: 272-13-19, 272-13-18 http://soc-human.kz/index.php/en/arhiv

(C) Қазақстан Республикасының Ұлттық ғылым академиясы, 2020

Типографияның мекенжайы: «NurNaz GRACE», Алматы қ., Рысқұлов көш., 103. 
Главный редактор

Почетный член НАН РК

T.O. Балыкбаев

Р едакционнная коллегия:

докт. экон. Н., проф., академик НАН РК У.Б. Баймуратов; докт. филос. н., проф., академик НАН РК Г.Е. Есим; докт. фил. Н., проф., академик НАН РК С.С. Кирабаев; докт. экон. Н., проф., академик НАН РК А.К. Кошанов; докт. экон. Н., проф., академик НАН РК К.Н. Нарибаев (заместитель главного редактора); докт. филос. н., проф., академик НАН РК А.Н. Нысанбаев; докт. юр. Н., проф., академик НАН РК С.Н. Саби-кенов; докт. юр. Н., проф., академик НАН РК М.К. Сулейменов; докт. экон. Н., проф., академик НАН РК С.С. Сатубалдин; докт. ист. н., проф., академик НАН РК Х.М. Абжанов; докт. ист. н., проф., чл.-корр. НАН РК М.Х. Абусеитова; докт. ист. Н., проф., академик НАН РК Б.А. Бай-танаев; докт. фил. н., проф., чл.-корр. НАН РК Б.А. Жакып; докт. фиолол. н., проф., академик НАН РК У.К. Калижанов; докт. фил. н., проф., академик НАН РК Д. Камзабекулы; докт. ист. н., проф., академик НАН РК Д.П. Кожамжарова; докт. ист. Н., проф., академик НАН РК М.К. Кой-гельдиев; докт. филол. н., проф., чл.-корр. НАН РК Ш. Курманбайулы; докт. ист. Н., проф., чл.-корр. НАН РК Ж.К. Таймаганбетов; докт. социол. н., проф., чл.-корр. НАН РК З.К. Шаукенова; д. филол. н., проф., чл.-корр. НАН РК А. Дербисали; доктор политических наук, проф., Бижанов А.К.; доктор ист. наук, проф., Кабульдинов 3.Е.; доктор филол. н., проф., член-корр. НАН РК Қажыбек Е.3.

$$
\text { Р е дакци онны й со в е т }
$$

академик НАН Республики Молдова Г. Белостечник (Молдова); академик НАН Азербайджанской Республики Н. Велиханлы (Азербайджан); академик НАН Республики Таджикистан Т.Н. Назаров (Таджикистан); академик НАН Республики Молдова А. Рошка (Молдова); академик НАН Республики Молдова Г. Руснак (Молдова); чл.-корр. НАН Азербайджанской Республики Ш. Мурадов (Азербайджан), член-корр. НАН Азербайджанской Республики 3.Сафарова (Азербайджан); д. э. н., проф. В.Н. Василенко (Украина); д.ю.н., проф. В.А. Устименко (Украина)

Известия Национальной академии наук Республики Казахстан. Серия общественных и гумани-тарных наук.

ISSN 2224-5294

Собственник: РОО «Национальная академия наук Республики Казахстан» (г. Алматы)

Свидетельство о постановке на учет периодического печатного издания в Комитете информации и архивов Министерства культуры и информации Республики Казахстан № 10894-Ж, выданное 30.04.2010 г.

Периодичность 6 раз в год

Тираж: 500 экземпляров

Адрес редакции: 050010, г. Алматы, ул. Шевченко, 28; ком. 219, 220; тел. 272-13-19, 272-13-18

http://soc-human.kz/index.php/en/arhiv 
Chief Editor

Honorary member of NAS RK

Balykbayev T.O

Editorial board:

Doctor of economics, prof, academician of NAS RK Baimuratov U.B.; doctor of philosophy, prof, academician of NAS RK Esim G.E.; doctor of philology, prof, academician of NAS RK Kirabayev S.S.; doctor of economics, prof, academician of NAS RK Koshanov A.K.; doctor of economics, prof, academician of NAS RK Naribayev K.N. (deputy editor-in-chief); doctor of philosophy, prof, academician of NAS RK Nyssanbayev A.N.; doctor of law, prof, academician of NAS RK Sabikenov S.N.; doctor of law, prof, academician of NAS RK Suleymenov M.K.; doctor of economy, prof, academician of NAS RK Satybaldin S.S.; doctor of history, prof, academician of NAS RK Abzhanov H.M; doctor of history, prof, corresponding member of NAS RK Abuseitova M.H.; doctor of history, prof, academician of NAS RK Baitanaev B.A.; doctor of philology, prof, corresponding member of NAS RK Zhakyp B.A.; doctor of philology, prof, academician of NAS RK Kalizhanov U.K.; doctor of philology, prof, academician of NAS RK Hamzabekuly D.; doctor of history, prof, academician of NAS RK Kozhamzharova D.P.; doctor of history, prof, academician of NAS RK Koigeldiev M.K.; doctor of philology, prof, corresponding member of NAS RK Kurmanbaiuly Sh.; doctor of history, prof, academician of NAS RK Taimaganbetov J.K.; doctor of sociology, prof, corresponding member of NAS RK Shaukenova Z.K.; doctor of philology, prof, corresponding member of NAS RK Derbisali A.; doctor of political science, prof Bizhanov A.K; doctor of History, prof Kabuldinov Z.E.; doctor of philology, prof, corresponding member of NAS RK Kazhybek E.Z.

\section{Editorial staff:}

Academician NAS Republic of Moldova Belostechnik.G (Moldova); Academician NAS Republic of Azerbaijan Velikhanli N. (Azerbaijan); Academician NAS Republic of Tajikistan Nazarov T.N. (Tajikistan); Academician NAS Republic of Moldova Roshka A. (Moldova) Academician NAS Republic of Moldova Rusnak G. (Moldova); Corresponding member of the NAS Republic of Azerbaijan Muradov Sh. (Azerbaijan); Corresponding member of the NAS Republic of Azerbaijan Safarova Z. (Azerbaijan); Associate professor of Economics Vasilenko V.N. (Ukraine), Associate professor of Law Ustimenko V.A. (Ukraine)

News of the National Academy of Sciences of the Republic of Kazakhstan. Series of Social and Humanities. ISSN 2224-5294

Owner: RPA "National Academy of Sciences of the Republic of Kazakhstan" (Almaty)

The certificate of registration of a periodic printed publication in the Committee of information and archives of the Ministry of culture and information of the Republic of Kazakhstan N 10894-Ж, issued 30.04.2010

Periodicity: 6 times a year

Circulation: 500 copies

Editorial address: 28, Shevchenko str., of. 219, 220, Almaty, 050010, tel. 272-13-19, 272-13-18

http://soc-human.kz/index.php/en/arhiv

(C) National Academy of Sciences of the Republic of Kazakhstan, 2020

Address of printing house: «NurNaz GRACE», 103, Ryskulov str, Almaty. 
N E W S

OF THE NATIONAL ACADEMY OF SCIENCES OF THE REPUBLIC OF KAZAKHSTAN

SERIES OF SOCIAL AND HUMAN SCIENCES

ISSN 2224-5294

Volume 2, Number 330 (2020), $40-48$

https://doi.org/10.32014/2020.2224-5294.35

UDC 336.11

IRSTI 68.75 .45

\author{
B.A. Markhayeva ${ }^{1}$, D.L. Kozbakhova ${ }^{2}$ \\ ${ }^{1}$ Almaty Management University, Almaty, Kazakhstan; \\ ${ }^{2}$ Turan-Astana University, Nur-Sultan, Kazakhstan. \\ E-mail: markhaeva@mail.ru,dkozbakhova@mail.ru
}

\title{
STATE AND PROBLEMS OF THE KAZAKHSTAN INSURANCE SECTOR DEVELOPMENT
}

\begin{abstract}
Dynamics of the insurance premiums volume in Kazakhstan for 2013-2017 years shows an increase of $33 \%$ in the national currency, while statistics in US dollars notes a decline in the insurance market by $39 \%$. The slowdown of the gross premium volumes in the insurance is due to the growth rates decrease in the general insurance sector compared to the continued significant growth in the life insurance segment. Volatility in the general insurance segment is determined, mainly, by the affiliated banking groups dependence strategy, which provides for an increase or decrease in the need for insurance against risks, accompanying changes in the loan portfolio. According to the experts from S\&P Global Ratings, Kazakhstan is at the stage of the insurance market formation, since its share in the GDP structure is less than $1 \%$, which is significantly lower than the indicators of developed countries with the insurance services penetration level more than $4 \%$ of GDP. This state allows us to conclude, that the most likely forecast scenario for the republican insurance market development can be called a neutral option with a sector share ranging from $1 \%$ to $2.5 \%$ of GDP.
\end{abstract}

Key words: insurance sector, insurance premium, forecast scenario.

Introduction. As of January 1, 2019 year, the Republic of Kazakhstan insurance sector assets are more than 1 trillion tenge, having increased by $13.2 \%$ over the year, sector revenues for 2018 year increased by $31.9 \%$ compared to 2017 year. At the same time industry expenses showed a slightly lower growth rate in 2018 year compared with the previous year amounting to $26.9 \%$. Net profit of the insurance sector at the end of 2018 year amounted to 81.5 billion tenge, which is on $51.1 \%$ more than in 2017 year [1, 2]. However, the real state, trends, factors and forecasts for the insurance sector development in Kazakhstan are somewhat modified, if they are not valued in the national currency, but in US dollars, as S\&P Global Ratings do for comparability. In the international market the main insurance premiums increase falls on emerging markets, including China, which in combination with for 2017 year showed the life insurance premiums volume increase by $14 \%$ and in the general insurance market by $6 \%$. If you look at the Kazakhstan insurance sector, then gross premiums for 5 years, from 2013 to 2017 years, show a growth of $33 \%$ in the national currency, statistics in US dollars for this period indicate the market decline by $39 \%[3,4]$.

The current state of the insurance market in Kazakhstan is far behind the world. Thus, the insurance rate in GDP of Switzerland is $11.9 \%$, Great Britain $-11.22 \%$, Holland - $9.41 \%$, France $-9.3 \%$, Finland $7.6 \%$, Belgium $-6.85 \%$, Germany $-6.54 \%$, Denmark $-6.3 \%$, Portugal $-5.42 \%$ and etc.

According to S\&P Global Ratings, in Kazakhstan, in addition to macroeconomic indicators the insurance sector in 2017 year showed the insurance premium decrease of $4 \%$ in real terms compared with a $9 \%$ increase in 2016 year. This slowdown is, mainly, due to the growth rates decrease in the general insurance sector by $6 \%$ in real terms in 2017 year compared to the continued significant growth in the life insurance segment by $11 \%$. According to experts, volatility in the general insurance segment of Kazakhstan is determined by the activities of several insurance companies, in particular, companies, 
involved in financial risk insurance for the affiliated banking groups. Such companies may demonstrate volatility in different years depending on the strategy of banking groups, which provides for the loan portfolios growth and a subsequent increase in the need for the risks insurance, associated with this growth $[3,4]$.

Methods. During this research such methods of scientific knowledge as analysis and synthesis, classification, generalization and analogy are widely used.

Results. As of January 1, 2019 year, the organizations number in the insurance sector of the Republic of Kazakhstan decreased to 29 due to the reorganization and merger of «Kazkommerts-Life» Life Insurance Company JSC» with «Halyk-Life» «Subsidiary Company of the Halyk Bank of Kazakhstan on Life Insurance» JSC. The structure dynamics of the republican insurance sector is presented in table 1.

Table 1 - The insurance sector structure of Kazakhstan for 2015-2018 years

\begin{tabular}{|c|c|c|c|c|}
\hline Institutional structure of the insurance sector & 01.01 .2016 & 01.01 .2017 & 01.01 .2018 & 01.01 .2019 \\
\hline $\begin{array}{l}\text { Number of insurance organizations, } \\
\text { including life insurance }\end{array}$ & $\begin{array}{c}33 \\
7\end{array}$ & $\begin{array}{c}32 \\
7\end{array}$ & $\begin{array}{c}32 \\
7\end{array}$ & $\begin{array}{c}29 \\
6\end{array}$ \\
\hline Number of insurance brokers & 15 & 15 & 16 & 15 \\
\hline Number of actuaries & 61 & 59 & 59 & 56 \\
\hline $\begin{array}{l}\text { The number of representative offices of nonresident insurance } \\
\text { organizations }\end{array}$ & 3 & 3 & 3 & 3 \\
\hline
\end{tabular}

The insurance premiums volume as of January 1, 2019 year increased by almost $4 \%$ compared with the same indicator as of January 1, 2018 year and amounted to 384.8 billion tenge. Voluntary property insurance is $39.3 \%$ of the total insurance premiums, compulsory insurance $-26.5 \%$, voluntary personal insurance $-34.1 \%$. The insurance premiums volume, collected since the beginning of 2018 year in the «life insurance» industry, amounted to 89.2 billion tenge, which is in $34.7 \%$ more, than for the same period in 2017 year.

The insurance premiums share, collected in the «life insurance» industry in total insurance premiums, amounted to $23.2 \%$, against $17.9 \%$ as of January 1, 2018 year. The insurance premiums volume, collected since the beginning of 2018 year in the «general insurance» industry, amounted to 295.6 billion tenge, which is in $2.7 \%$ less, than for the same period in 2017 year (table 2).

Table 2 - The insurance premiums dynamics in Kazakhstan

\begin{tabular}{|c|c|c|c|c|c|c|c|c|}
\hline \multirow[b]{2}{*}{ Insurance premiums } & \multicolumn{2}{|c|}{01.01 .2016} & \multicolumn{2}{|c|}{01.01 .2017} & \multicolumn{2}{|c|}{01.01 .2018} & \multicolumn{2}{|c|}{01.01 .2019} \\
\hline & $\begin{array}{l}\text { million } \\
\text { tenge }\end{array}$ & $\begin{array}{c}\text { in } \% \text { to } \\
\text { total }\end{array}$ & $\begin{array}{l}\text { million } \\
\text { tenge }\end{array}$ & $\begin{array}{c}\text { in } \% \text { to } \\
\text { total }\end{array}$ & $\begin{array}{l}\text { million } \\
\text { tenge }\end{array}$ & $\begin{array}{c}\text { in } \% \text { to } \\
\text { total }\end{array}$ & $\begin{array}{l}\text { million } \\
\text { tenge }\end{array}$ & $\begin{array}{c}\text { in } \% \text { to } \\
\text { total }\end{array}$ \\
\hline Total by insurance industry & 288272 & 100.0 & 356904 & 100.0 & 370174 & 100.0 & 384846 & 100.0 \\
\hline Life insurance & 55044 & 19.1 & 55739 & 15.6 & 66205 & 17.9 & 89215 & 23.2 \\
\hline General insurance & 233228 & 80.9 & 301165 & 84.4 & 303969 & 82.1 & 295631 & 76.8 \\
\hline
\end{tabular}

The dynamics analysis of the absolute and relative profitability indicators for the period from 2015 to 2018 years reveals the following problems in the national insurance sector development. Although industry revenues for 2018 year increased by 93.8 billion tenge compared to 2017 year, but they still did not reach the level of 2015 year. The net profit of the insurance sector in 2018 year increased by more than $50 \%$, but compared to 2015 year, it is in 2 times lower. The net profit return on assets ratio amounted to $8.3 \%$, the net profit return to equity ratio $-18.6 \%$. These indicators are in 2.5 and 2.3 times lower than the 2015 year level, respectively (table 3 ). 
Table 3 - The dynamics of the absolute and relative profitability indicators of the insurance sector of Kazakhstan (million tenge)

\begin{tabular}{|l|l|l|l|l|l|}
\hline No. & Indicators & 01.01 .2016 & 01.01 .2017 & 01.01 .2018 & 01.01 .2019 \\
\hline 1 & Insurance sector revenues & 451965 & 298674 & 291723 & 384807 \\
\hline 2 & Insurance sector net profit & 174475 & 68059 & 53974 & 81552 \\
\hline 3 & Insurance sector assets & 825683 & 853627 & 926043 & 1048510 \\
\hline 4 & Return on assets (n.2/n.3 x 100), \% & 21.1 & 8.0 & 5.8 & 8.3 \\
\hline 5 & Equity & 406358 & 397017 & 411100 & 468000 \\
\hline 6 & Return on equity, (n.2/n.5 x 100), \% & 42.9 & 17.1 & 13.1 & 18.6 \\
\hline Note - made on the basis of [1,2]
\end{tabular}

The dynamics analysis of macroeconomic indicators shows that as of January 1, 2019 year, the assets share of the insurance sector in the republic's GDP is $1.78 \%$, the insurance premiums share in GDP is $0.65 \%$, the insurance premiums ratio per capita is 20920 tenge (table 4 ).

Table 4 - The macroeconomic indicators of the insurance sector of the Republic of Kazakhstan for 2015-2018 years

\begin{tabular}{|l|l|l|l|l|}
\hline $\begin{array}{l}\text { Main indicators of the } \\
\text { insurance sector }\end{array}$ & 01.01 .2016 & 01.01 .2017 & 01.01 .2018 & 01.01 .2019 \\
\hline GDP, billion tenge & $\mathbf{4 1 3 0 8}$ & 46971 & 53101 & 58786 \\
\hline The assets ratio to GDP, \% & $\mathbf{2 . 0 0}$ & 1.82 & 1.74 & 1.78 \\
\hline The equity ratio to GDP, \% & $\mathbf{0 . 9 8}$ & 0.85 & 0.77 & 0.80 \\
\hline The insurance premiums ratio to GDP, \% & $\mathbf{0 . 7}$ & 0.76 & 0.70 & 0.65 \\
\hline The insurance premiums ratio per capita, tenge & $\mathbf{1 6 3 3 1 . 4}$ & 20103.6 & 20387.3 & 20920.4 \\
\hline Note - made on the basis of [1, 2, 3] & \multicolumn{3}{|l}{} \\
\hline
\end{tabular}

As you can see, insurance expenses per capita in Kazakhstan also remain quite low - 62 US dollars, which is below average level. This indicator varies significantly in developed and developing countries, on average from 3500 to 150 US dollars, respectively. For example, in Russia it is equal to 152, Georgia - 46, Azerbaijan - 33 US dollars. The low growth rate of disposable income in these countries does not support the development of the insurance sector: the population purchases, mainly, basic necessities and therefore does not always choose adequate insurance coverage $[4,5]$.

As for research on the insurance market growth dynamics forecast, comparing traditional methods and methods of alternative scenarios, we can state that, in a qualitatively transforming socio-economic environment, focusing on predicting the insurance business quantitative parameters is ineffective and leads to complete inaccuracy in market growth forecasting. According to A.Sembekov, the fundamental lack of quantitative forecasting options, associated with bringing down the calculated rates reliability increasing as far as forecast period extension, has a negative impact on strategic decisions on the insurance business development. It is efficient to complete the use of the alternative forecast scenarios methods with the quantitative forecasts development, first of all, characterizing the insurance market dynamics as a whole, for example, the insurance rate ratio in GDP and others [6].

Therefore, A. Sembekov, using the example of the insurance ratio quantitative calculations with a mathematical model, shows the possibility of updating the forecast after certain periods for the long term in Kazakhstan. To simulate the process of GDP growth and insurance premiums, the logistic curve formula is used:

$$
y=\frac{L}{1+a e^{-b t}}
$$

where $L$ is the function extreme value; $y, a, b$ are the formula parameters, which are calculated, based on the actual values of the time series; $t$ is a time parameter [6]. Logistic curves are used for the mathematical description of time series, when the dynamics of the series levels first go with high growth rates, and then the growth begins to slow down. The parameter $L$ is found by the variative method, based on the condition, that the calculated values of the parameters $a$ and $b$ will guarantee reliability for the correlation index with an error probability of 0.01 , taking into account the Student distribution. 
Isseveroglu and Gucenme, comparing the possibilities of logit, discriminant and regression analysis for predicting and early detection of the insurance companies experiencing financial decrease, based on data from 45 companies, operating in non-life insurance sectors, from 1992 to 2006 years, note the slightly better predictive ability and great potential of the logit-model in comparison with the other two models [7].

According to A. Sembekov, in conditions of high uncertainty in the long-term prospects of Kazakhstan's foreign economic cooperation when forecasting the insurance market growth, it is advisable to use a detailed version of the alternative scenario methodology, i.e. move beyond three scenarios (optimistic, neutral, pessimistic), but consider five alternative scenarios, including also moderateoptimistic and moderate-pessimistic options. The author states that the trends in the development of Kazakhstan's insurance business make it possible to characterize moderate-pessimistic and pessimistic scenarios as unlikely, possible only as a result of a deep crisis in the global economy. Summarizing the comparison of alternative forecast scenarios for the development of the insurance market, A. Sembekov confirms that the most likely is a moderate-optimistic scenario, suggesting an increase in the insurance activity share in Kazakhstan's GDP over 2.5-3.5 \% by 2019 year [6].

Discussion. For comparison, Zheng et al., estimating the average annual growth rate of China's GDP from 2006 to 2020 years at $6 \%-9 \%$, conclude that the possible range of growth rates for China's insurance industry will be $7.7 \%-17.9 \%$, with a more likely range of $9.8 \%-14.8 \%$. In the middle scenario the average annual real growth rate of the insurance industry in China during this period will be $12.3 \%$. Calculations show that by 2020 year the size of China's insurance market will be in 5.7 times larger, than in 2005 year, and the overall insurance rate penetration will be $5.6 \%$, while $4 \%$ will be in life insurance, and $1.6 \%$ - for non-life insurance. The growth rate of the Chinese insurance industry from 2006 to 2020 years will almost exceed in double the global average rates, and by 2020 year, China's share in the world insurance market will be about $4 \%$. At the same time, the authors admit that there are other factors, such as social, political, cultural, demographic and market structures, which also affect the insurance industry, but the key factor in the long term perspective is the growth and development of the economy as a whole [8].

Ranger and Surminski predict that gross premiums volume in non-life insurance in BRICS countries could increase at a rate of $5.4 \%$ to $12.3 \%$ per year over the next decade, depending on the country. The authors consider these trends through 2030 year in terms of climate change and state that the impact of climate change will be more multifaceted, complex and regionally variable than previously thought. In response, five pathways are proposed, such as welfare, willingness to pay for the insurance, policies and regulations, changes in the insurance supply and new opportunities, related to adaptation and mitigation [9].

$\mathrm{Xu}$ and Liu, analyzing the impact of macroeconomic indicators on the demand for life insurance in China with using monthly data for 2001-2010 years, state that GDP has a positive effect on life insurance premiums, and this effect is significant and constant, while inflation has a relatively small negative impact. At the same time, in the long term perspective change in interest rates and stock indexes similarly have a positive effect on the insurance premiums [10].

Petkovski and Kjosevski, examining the insurance consumption determinant in 16 countries of Central and Southeast Europe from 1992 to 2011 years, note that in the long term perspective GDP per capita and the number of cars per 1000 people positively and significantly affect unconnected consumption with life insurance [6]. Similarly in Kazakhstan the insurance premiums growth in 2018 year in the «general insurance» industry (table 2) is due to an increase in car sales and an annual increase in the minimum tariff for compulsory third party car insurance [11].

Masarova and Ivanova, analyzing the differences in the insurance markets development in Slovakia and the Czech Republic, the insurance market, its size, efficiency, value from the national economy point of view, characterize by such indicators, as gross premiums, insurance payments, gross premiums to GDP, gross premiums per capita and others. The study shows that in Slovakia insurers prefer life insurance, while property protection prevails in the Czech Republic. In the Czech insurance market penetration and density are much higher, than in Slovakia. Nevertheless, in these countries the economy underinsurance is still preserved and there is significant growth potential due to the new market production and expansion [12].

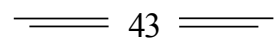


Li and Song state that the study of the insurance company solvency to build a rating system helps provide theoretical support and an empirical basis for supervision and control by the relevant government agency. The financial standing empirical analysis of seven typical Chinese companies in the domestic life insurance market based on factor and correlation data analysis for the period from 2007 to 2012 years shows that solvency can be described not only by the internal factors, such as capital structure and size of premiums, asset quality, growth and profitability, but also related to the external factors, such as GDP growth rates, inflation rate and real interest rates, which, in its turn, support the theory of qualitative analysis [13].

Kaya based on a study of specific factors, affecting the profitability of 24 Turkish non-life insurance companies, from 2006 to 2013 years, concludes that such factors include company size, company age, loss ratio, current ratio and the premium growth rate [14].

According to Dewi and Mahfudz, an insurance company has distinctive characteristics therefore it is necessary to use specific ratios, developed by the USA National Association of Insurance Commissioners in assessing its activity. The authors study the influence of financial ratios in order to predict the likelihood of financial difficulties, financial deterioration before the bankruptcy of 63 general insurance companies, registered in the Indonesia Insurance Directory from 2010 to 2014 years. The study results based on logistic regression show that changes in the loss and liquidity ratios have a positive and significant impact on the occurrence of financial difficulties, while changes in the surplus ratios, the premium growth and risk capital do not create financial problems for the insurance company [15].

Lee and Lin study the impact of globalization, political institutions, and financial liberalization on the activity results and risk taking by the insurance companies, covering 1324 individual firms in selected 30 OECD countries. The authors note that the increased globalization and a stable political environment help to reduce risks for the insurers. In contrast, financial liberalization has the opposite effect on the insurance company`s activity results. These findings are important for the insurance markets competitors and national policy makers [16].

Peleckis et al. state that as a result of globalization in the insurance industry in three Baltic countries and Slovenia the number of national insurance companies decreased and the number of foreign branches increased. Analysis of statistics on the level of concentration shows a tendency for increasing competition between insurance companies in the studied countries. Using density index and insurance penetration, the authors note a different level of demand for the insurance services in these countries depending on economic growth and globalization. So, in 2015 year, the insurance density in Lithuania was 1.6\%, and the average insurance cost per capita was 204 Euros. Penetration and density of the Latvian insurance market, respectively, amounted to $1.5 \%$ and 185 Euros, Estonia $-1.7 \%$ and 259 Euros, Slovenia $-5.1 \%$ and 920 Euros, while the average penetration and density ratio in the countries of the Central and East European EU regions accounted for $2.6 \%$ and 334 Euros, respectively [17].

Shinet, Abdibekov and Koptayeva suggest moving from subsidizing insurance payments to subsidize $50 \%$ of insurance premiums, that will contribute to the objective distribution of subsidies between producers and reduce the cost of agricultural products. Authors also propose to revise the methodology for calculating insurance tariffs in Kazakhstan, taking into account the agroclimatic zones, which could expand the list of insurance services in the agriculture [18].

Conclusion. Instability in the global financial markets can adversely affect the dynamics of GDP, the volume of bank lending and consumer activity. Ultimately it will affect the slowdown in demand recovery for voluntary and imputed insurance types. In case, if a negative scenario is being realized, the insurance premiums decline will lead to a repeat of the liquidity shortage scenario and a new wave of the insurance companies' bankruptcies. Opportunities for the insurance sector development can be both internal and external. The low level of the insurance penetration or the level of risks non-insurance, in the economy of Kazakhstan varies from 10 to $90 \%$ depending on the insurance type. This fact opens the opportunities for an extensive premiums growth. The highest level of the underinsurance is observed in such segments of the insurance market as accumulative life insurance, property insurance for individuals, property and liability insurance for small and medium-sized businesses, and various types of voluntary insurance in the regional insurance markets.

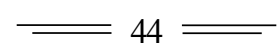


Another possibility could be a growing interest in the insurance industry by the state. The introduction of new compulsory insurance types can have significant positive external effects, including affecting the insurance infrastructure development among insurers and the insurance culture among insurant, which will have an even stronger long-term effect on the insurance demand growth.

However, the experience of the developed countries shows that the insurance market growth opportunities are associated not only with the strengthening of the state role. Thus, Tynkkynen et al. note that in the Scandinavian countries over the past decades there has been a significant increase in the number of voluntary private health insurance (VPHI) contracts. According to the authors, the entry of the VPHI market is a response to gaps in national health systems, created by the institutional context, political decisions and cultural interpretations of the system functioning. However, once the VPHI market is created, it introduces a new dynamic, which is less associated with gaps and inflexibility, and more - with cultural factors [19].

In our opinion, the trends and forecasts for the insurance sector growth in Kazakhstan in the coming years will be determined by the strong influence of digital transformation, the rapid information technology development, in the number increase of Internet users and, as a result, IT insurance and electronic commerce will expand. Recent developments in the insurance industry cover various innovations in the field of insurance technology (InsurTech). New digital products and technologies can become growth areas as both in terms of sales increasing, and so improving the insurance company service.

For example, Kong and Chen note that three main models of Internet insurance have been formed in China so far: a network platform, managed by the traditional insurance companies themselves; a thirdparty network platform and professional Internet insurance companies. From the point of view of the current market structure, the third-party platform model dominates, while the professional Internet insurance companies show a new force of sudden growth. Such companies have unique advantages in solvency, profitability, growth ability and operational capabilities, but, on the other hand, they are characterized by a weak ability to manage costs, return on investment and business development, and so on [20].

Developing countries are still lagging behind developed markets in terms of volume indicators and premium structure; so far, insurance culture is only forming here. The premiums structure is dominated by simple insurance products, such as car insurance, which is also characteristic of the current state of the insurance sector in Kazakhstan. According to S\&P Global Ratings experts, Kazakhstan is at the stage of the insurance market formation, since by the end of 2018 year the insurance sector share in the GDP structure is less than $1 \%$. This is a relatively low indicator compared to developed countries, where the insurance services penetration rate is more than $4 \%$ of GDP. Such statistics allows, in our opinion, to conclude, that the most likely scenario for the insurance market development of Kazakhstan in the coming years can be called a neutral, or pragmatic, option with a sector share ranging from $1 \%$ to $2.5 \%$ of the country's GDP.

\title{
Б.А. Мархаева ${ }^{1}$, Д.Л. Козбахова ${ }^{2}$
}

\author{
${ }^{1}$ Алматы Менеджмент Университеті, Алматы, Қазақстан; \\ ${ }^{2}$ «Тұран-Астана» Университеті, Нұр-Сұлтан, Қазақстан

\section{ҚАЗАҚСТАН САҚТАНДЫРУ СЕКТОРЫНЫН ЖАҒДАЙЫ ЖӘНЕ ДАМУ МӘСЕЛЕЛЕРІ}

\begin{abstract}
Аннотация. Қазақстан Республикасы сақтандыру секторының табыстары 2017 жылмен салыстырғанда 2018 жылы 31,9 \% -ға өскен. 2018 жылдың аяғында сектордың таза пайдасы 81,5 млрд. теңгені құрады, сондай-ақ бұл көрсеткіш өткен кезеңмен салыстырғанда, 51,1 \%-ға көбейген. Егер ұлттық валютада емес, S\&P Global Ratings компаниясы сияқты салыстыру мақсатында АҚШ-тың долларымен өлшейтін болсақ, Қазақстан сақтандыру секторының нақты жағдайы, беталыстары, факторлары мен даму болжамдары біршама өзгеше сипатталады. Компанияның бағалауы бойынша, Қазақстандағы макроэкономикалық көрсеткіш-
\end{abstract}


тердің ішінде сақтандыру секторы 2016 жылдағы 9 \%-ға өсумен салыстырғанда, 2017 жылғы сақтандырудың брутто-сыйлықтар көлемі 4 \%-ға төмендегінін нақты көрсетті. Бұл бәсеңдеу өмірді сақтандыру сегментінде сақталып келе жатқан өсу қарқынына қарағанда, жалпы сақтандыру секторындағы өсу қарқынының төмендеуімен түсіндіріледі. Жалпы сақтандыру сегментінің құбылмалылығы, негізінен несие қоржынының өзгеруімен ілесіп жүретін тәукелді сақтандыруға деген қажеттіліктің өсуін немесе төмендеуін ескеретін үлестес банк топтарының стратегиясына тәуелділігімен орын алады.

2017 жылмен салыстырғанда, 2018 жылы сақтандыру секторының табыстары 93,8 млрд. теңгеге көбейгеніне қарамастан, олардың көлемі 2015 жылдың деңгейіне жетпеген. 2018 жылдың қорытындысы бойынша, сақтандыру секторының таза пайдасы 50 \%-ға өскен, бірақ 2015 жылмен салыстырғанда бұл көрсеткіш 2 есе төмен екені байқалады. Таза пайданың жалпы активтерге қатысы (ROA) 8,3 \%-ды құраса, ал таза пайданың меншікті капиталға қатысы (ROE) 18,6 \%-ға тең болды. Аталған көрсеткіштер 2015 жылмен салыстырғанда, сәйкесінше, 2,5 және 2,3 есе төмен екені ескеріледі.

Әлемдік қаржы нарықтарындағы тұрақсыздық ЖІӨ-нің динамикасы, банктік несиелеудің көлемдері және тұтынушылық белсенділікке келеңсіз әсер етуі мүмкін. Ақыр аяғында бұл жағдай сақтандырудың ерікті және жүктелген түрлеріне деген сұраныстың қалпына келу қарқынының бәсеңдеуіне әсер етеді. Сақтандыру секторының даму мүмкіндері ішкі және сыртқы да болуы мүмкін. Сақтандырудың ену деңгейінің төмендігі, яғни тәукелдікті сақтандырудың жеткіліксіз деңгейі Қазақстан экономикасында сақтандыру түріне байланысты 10 \%-дан 90 \%-ды құрайды. Бұл жағдай сақтандыру жарналарының экстенсивті өсуіне мүмкіндік жаратады. Сақтандыру жеткіліксіздігінің ең жоғары деңгейі аймақтық сақтандыру нарықтарындағы өмірді жинақтаушы сақтандыру, жеке тұлғалардың мүлкін сақтандыру, кіші және орта бизнестің мүлкі мен жауапкершілігін сақтандыру, ерікті сақтандырудың түрлері сияқты сақтандыру секторының сегменттерінде байқалады. Басқа да мүмкіндік ретінде сақтандыру саласына мемлекет тарапынан қызығушылықтың артуын атап өтуге болады. Сақтандырудың жаңа міндетті түрлерін енгізу едәуір оң сыртқы әсерлерге алып келуі мүмкін, соның ішінде сақтандырушының сақтандыру инфрақұрылымы және сақтанушының сақтандыру мәдениетінің дамуына өз ықпалын тигізуі мүмкін. Бұл, өз кезегінде, сақтандыруға деген сұраныстың өсуіне ұзақ мерзімді әсерін тигізетін сияқты.

Біздің пікірімізге сәйкес, Қазақстан сақатандыру секторының жақын жылдардағы беталыстары мен болжамдары сандық түрлендірудің күшті әсерімен, ақпараттық технологиялардың қарқынды дамуымен, интернетті пайдаланушылар санының көбейуімен қамтамасыз етіледі. Нәтижесінде IT-сақтандыру және электрондық коммерция ұлғаяды. Жаңа сандық өнімдер мен технологиялар сақтандыру компаниясы сатуларының кобеюі және оның қызметінің жақсаруының да өсу нүктелері болуы мүмкін.

S\&P Global Ratings компаниясы сарапшыларының пікірі бойынша, Қазақстан өзінің сақтандыру нарығының қалыптасу кезеңінде тұр, себебі осы нарықтың ЖІӨ-нің құрамындағы үлесі 1 \%-дан кем, ал бұл көрсеткіш сақтандыру қызметінің ену деңгейі ЖІӨ-нің 4 \%-ын құрайтын дамыған елдермен салыстырғанда, едәуір төмен болып саналады. Мұндай жағдай республиканың сақтандыру нарығы дамуының ең ықтимал болжамды сценарийі ретінде сектордың ЖІӨ-нің 1 \%-ы мен 2,5 \%-н құрайтын үлесімен сипатталатын бейтарап нұсқасын қарастыруға болады деген қорытынды жасауға мүмкіндік береді.

Түйін сөздер: сақтандыру секторы, сақтандыру сыйлықтары, болжамды сценарий.

\section{Б.А. Мархаева ${ }^{1}$, Д.Л. Козбахова ${ }^{2}$}

${ }^{1}$ Алматы Менеджмент Университет, Алматы, Казахстан;

${ }^{2}$ Университет «Туран-Астана», Нур-Султан, Казахстан

\section{СОСТОЯНИЕ И ПРОБЛЕМЫ РАЗВИТИЯ СТРАХОВОГО СЕКТОРА КАЗАХСТАНА}

Аннотация. Доходы страхового сектора Республики Казахстан за 2018 год по сравнению с 2017 годом увеличились на 31,9 \% . Чистая прибыль сектора на конец 2018 года составила 81,5 млрд. тенге, что на $51,1 \%$ больше, чем за прошлый период.. Однако реальное состояние, тенденции, факторы и прогнозы развития страхового сектора Казахстана несколько видоизменяются, если их оценивать не в национальной валюте, а в долларах США, как это делает для соспоставимости S\&P Global Ratings. По оценкам компании, в Казахстане на фоне макроэкономических показателей страховой сектор в 2017 году продемонстрировал снижение объёмов страховой премии-брутто на 4\% в реальном выражении в сравнении с ростом на $9 \%$ в 2016 году. Это замедление обусловлено, главным образом, снижением темпов роста в секторе общего страхования на 6\% в реальном выражении в 2017 году по сравнению с сохраняющимся значительным ростом в сегменте страхования жизни на 11 \%. По мнению экспертов, волатильность в сегменте общего страхования 
Казахстана определяется деятельностью нескольких страховых компаний, в частности, компаний, занимающихся страхованием финансовых рисков для аффилированных банковских групп. Такие компании могут демонстрировать в разные годы волатильность в зависимости от стратегии банковских групп, предусматривающей рост кредитных портфелей и последующее увеличение потребности в страховании рисков, сопряженных с этим ростом.

Хотя доходы отрасли за 2018 год увеличились на 93,8 млрд. тенге по сравнению с 2017 годом, но они так и не достигли уровня 2015 года. Чистая прибыль страхового сектора за 2018 год увеличилась более чем на $50 \%$, однако по отношению к 2015 году она в 2 раза ниже. Отношение чистой прибыли к совокупным активам (ROA) составило 8,3 \%, отношение же чистой прибыли к собственному капиталу по балансу (ROE) 18,6 \% Эти показатели ниже уровня 2015 года соответственно в 2,5 и 2,3 раза.

Нестабильность на мировых финансовых рынках может негативно сказываться на динамике ВВП, объёмах банковского кредитования и потребительской активности. В конечном итоге это отразится на замедлении темпов восстановления спроса на добровольные и вменённые виды страхования. Возможности развития страхового сектора могут быть как внутренними, так и внешними. Невысокий уровень проникновения страхования, или уровень недострахования рисков, в экономике Казахстана варьируется от 10 до $90 \%$ в зависимости от вида страхования. Это обстоятельство открывает возможности для экстенсивного роста взносов. Наибольший уровень недострахования отмечается в таких сегментах страхового рынка, как накопительное страхование жизни, страхование имущества физических лиц, страхование имущества и ответственности малого и среднего бизнеса, различные виды добровольного страхования на региональных страховых рынках. Другой возможностью может быть рост интереса к страховой отрасли со стороны государства. Введение новых обязательных видов страхования может иметь значительные положительные внешние эффекты, в том числе повлиять на развитие страховой инфраструктуры у страховщиков и страховой культуры у страхователей, что окажет ещё более сильное долгосрочное влияние на рост спроса на страхование.

На наш взгляд, тенденции и прогнозы развития страхового сектора Казахстана в ближайшие годы будут определяться сильным влиянием цифровой трансформации, стремительным развитием информационных технологий, увеличением числа пользователей интернета и, как результат, расширятся IT-страхование и электронная коммерция. Новые цифровые продукты и технологии могут стать точками роста как в части увеличения продаж, так и улучшения сервиса страховой компании.

По мнению экспертов S\&P Global Ratings, Казахстан находится на этапе становления страхового рынка, поскольку к концу 2018 года доля страхового сектора в структуре ВВП составляет менее $1 \%$. Это относительно низкий показатель по сравнению с развитыми странами, где уровень проникновения страховых услуг составляет более 4 \% от ВВП. Такая статистика позволяет, на наш взгляд, сделать вывод, что наиболее вероятным сценарием развития страхового рынка Казахстана в ближайшие годы можно назвать нейтральный, или прагматический, вариант с долей сектора в пределах от 1 \% до 2,5 \% к ВВП республики.

Ключевые слова: страховой сектор, страховые премии, прогнозный сценарий.

Information about authors:

Markhayeva Bayanslu is a professor of Higher School of Management, Almaty Management University, Almaty, Kazakhstan, a doctor of economic sciences, markhaeva@mail.ru, https://orcid.org/0000-0002-7354-7125

Kozbakhova Dinara is a senior lecturer of Turan-Astana University, Nur-Sultan, Kazakhstan, a master of Economics, dkozbakhova@mail.ru, https://orcid.org/0000-0002-3526-989X

\section{REFERENCES}

[1] The current state of the insurance sector of the Republic of Kazakhstan as of January 1, 2018. National Bank of Kazakhstan. Almaty, 2018. www.nationalbank.kz (in Russian)

[2] The current state of the insurance sector of the Republic of Kazakhstan as of January 1, 2019. National Bank of Kazakhstan. Almaty, 2019. www.nationalbank.kz (in Russian).

[3] Ministry of National Economy of the Republic of Kazakhstan. Statistics committee. 2019. https://stat.gov.kz/official/dynamic (in Russian).

[4] The insurance market of Kazakhstan in the international aspect: development dynamics. 11.10.2018. allinsurance.kz (in Russian).

[5] Why Kazakhstan insurance market is narrowing. 30.12.2018. forbes.kz (in Russian).

[6] Sembekov A.K. Ustojchivoe razvitie strahovogo rynka v Respublike Kazahstan: teorija, metodologija i prioritety: [Sustainable development of the insurance market in the Republic of Kazakhstan: theory, methodology and priorities. Extended Abstract of D.Sc. Thesis]. Karaganda, 2006. - 48 s. (in Russian).

[7] Isseveroglu G., Gucenme U. (2010) Early warning model with statistical analysis procedures in Turkish insurance companies. African Journal of Business Management. Volume 4. Issue 5. Pp. 623-630. (in Eng). 
[8] Zheng W., Liu Y.D., Dickinson G. (2008) The Chinese insurance market: Estimating its long-term growth and size. Geneva Papers on Risk and Insurance: Issues and Practice. Volume 33. Issue 3. Pp. 489-506. DOI: 10.1057/gpp.2008.19. (in Eng).

[9] Ranger N., Surminski S. (2013) A preliminary assessment of the impact of climate change on non-life insurance demand in the BRICS economies. International Journal of Disaster Risk Reduction. Volume 3. Pp. 14-30. DOI: 10.1016/j.ijdrr.2012.11.004. (in Eng).

[10] Xu L., Liu J.X. (2011) Analysis on the dynamic correlation between China life insurance demand and macro-economy. Proceedings of the 2nd China International Conference on Insurance and Risk Management (CICIRM), 2011. Pp. 229-237. (in Eng).

[11] Petkovski M., Kjosevski J. (2014) An Analysis of Non-Life Insurance Determinants for Selected Countries in Central and South Eastern: a Co-Integration Approach. Romanian Journal of Economic Forecasting. Volume 17. Issue 3. Pp. 160-178. (in Eng).

[12] Masarova J., Ivanova E. (2016) Development Indicators Comparison of Insurance Markets in Slovakia and Czech Republic. Proceedings of the 1st International Conference Contemporary Issues in Theory and Practice of Management (CITPM), 2016. Pp. 281-287. (in Eng).

[13] Li P., Song P.F. (2015) The Analysis of Solvency Evaluation System for Life Insurance Company in China. Proceedings of the 5th China International Conference on Insurance and Risk Management (CICIRM), 2014. Pp. 66-79. (in Eng).

[14] Kaya E.O. (2015) The Effects of Firm-Specific Factors on the Profitability of Non-Life Insurance Companies in Turkey. International Journal of Financial Studies. Volume 3. Issue 4. Pp. 510-529. DOI: 10.3390/ijfs3040510. (in Eng).

[15] Dewi T.T.C., Mahfudz (2017) Effect of Change in Surplus Ratio, Incurred Loss Ratio, Liquidity Ratio, Premium Growth Ratio, Size and Risk Based Capital to Predict the Possibilities of Financial Distress: The Case of Indonesian Non-Life Insurance Listed in Indonesia Insurance Directory. Advanced Science Letters. Volume 23. Issue 8. Pp. 7285-7288. DOI: 10.1166/asl.2017.9352. (in Eng).

[16] Lee C.C., Lin C.W. (2016) Globalization, political institutions, financial liberalization, and performance of the insurance industry. North American Journal of Economics and Finance. Volume 36. Pp. 244-266. DOI: 10.1016/j.najef.2016.01.007. (in Eng).

[17] Peleckis K., Peleekiene V., Lace N., Polajeva T., Nedelko Z., Potocan V. (2016) Globalization of Insurance Industy. Globalization and its Socio-Economic Consequences, 16th International Scientific Conference Proceedings. PTS I-V. Pp. 16491656. (in Eng).

[18] Shinet G.G., Abdibekov S.U., Koptayeva G.P. (2019) State regulation of insurance system in agriculture of the Republic of Kazakhstan. News of the National Academy of Sciences of the Republic of Kazakhstan. Series of Social and Human Sciences. Volume 5, Number 327 (2019), pp. 28-35. ISSN 2224-5294. (in Eng). https://doi.org/10.32014/2019.2224-5294.159

[19] Tynkkynen L.K., Alexandersen N., Kaarboe O., Anell A., Lehto J., Vrangbaek K. (2018) Development of voluntary private health insurance in Nordic countries - An exploratory study on country-specific contextual factors. Health Policy. Volume 122. Issue 5. Pp. 485-492. DOI: 10.1016/j.healthpol.2018.03.008. (in Eng).

[20] Kong Y.H., Chen S.Y. (2016) A Study on Development Strategies of Professional Internet Insurance Company: Comparative Analysis on Key financial indicators of Online \& Offline Insurance Companies. Proceedings of the 7th China International Conference on Insurance and Risk Management (CICIRM), 2016. Pp. 295-307. (in Eng). 


\title{
PUBLICATION ETHICS AND PUBLICATION MALPRACTICE IN THE JOURNALS OF THE NATIONAL ACADEMY OF SCIENCES OF THE REPUBLIC OF KAZAKHSTAN
}

For information on Ethics in publishing and Ethical guidelines for journal publication see http://www.elsevier.com/publishingethics and http://www.elsevier.com/journal-authors/ethics.

Submission of an article to the National Academy of Sciences of the Republic of Kazakhstan implies that the work described has not been published previously (except in the form of an abstract or as part of a published lecture or academic thesis or as an electronic preprint, see http://www.elsevier.com/postingpolicy), that it is not under consideration for publication elsewhere, that its publication is approved by all authors and tacitly or explicitly by the responsible authorities where the work was carried out, and that, if accepted, it will not be published elsewhere in the same form, in English or in any other language, including electronically without the written consent of the copyrightholder. In particular, translations into English of papers already published in another language are not accepted.

No other forms of scientific misconduct are allowed, such as plagiarism, falsification, fraudulent data, incorrect interpretation of other works, incorrect citations, etc. The National Academy of Sciences of the Republic of Kazakhstan follows the Code of Conduct of the Committee on Publication Ethics (COPE), and follows the COPE Flowcharts for Resolving Cases of Suspected Misconduct (http://publicationethics.org/files/u2/New_Code.pdf). To verify originality, your article may be checked by the originality detection service Cross Check http://www.elsevier.com/editors/plagdetect.

The authors are obliged to participate in peer review process and be ready to provide corrections, clarifications, retractions and apologies when needed. All authors of a paper should have significantly contributed to the research.

The reviewers should provide objective judgments and should point out relevant published works which are not yet cited. Reviewed articles should be treated confidentially. The reviewers will be chosen in such a way that there is no conflict of interests with respect to the research, the authors and/or the research funders.

The editors have complete responsibility and authority to reject or accept a paper, and they will only accept a paper when reasonably certain. They will preserve anonymity of reviewers and promote publication of corrections, clarifications, retractions and apologies when needed. The acceptance of a paper automatically implies the copyright transfer to the National Academy of sciences of the Republic of Kazakhstan.

The Editorial Board of the National Academy of sciences of the Republic of Kazakhstan will monitor and safeguard publishing ethics.

Правила оформления статьи для публикации в журнале смотреть на сайте:

\author{
www:nauka-nanrk.kz \\ http://soc-human.kz/index.php/en/arhiv \\ Редакторы: М. С. Ахметова, Г. Б. Халидуллаева, Д. С. Аленов \\ Верстка на компьютере А.М. Кульгинбаевой \\ Подписано в печать 19.03..2020 \\ Формат 60x881/8. Бумага офсетная. Печать - ризограф. \\ 14 п.л. Тираж 500. Заказ 2.
}

Национальная академия наук $Р К$

050010, Алматы, ул. Шевченко, 28, т. 272-13-18, 272-13-19 